\title{
The commuting behavior of workers in the United States: differences between the employed and the self- employed
}

\author{
J. Ignacio Gimenez-Nadal, University of Zaragoza (Spain) and CTUR (Oxford) \\ Jose Alberto Molina, University of Zaragoza (Spain) and IZA (Germany) \\ Jorge Velilla, University of Zaragoza (Spain)
}

\begin{abstract}
In this paper, we analyze the commuting behavior of workers in the United States, with a focus on the differences between employees and the self-employed. Using the American Time Use Survey for the years 2003-2014, our empirical results show that employees spend 7.22 more minutes per day to commuting than their self-employed counterparts, which represents a difference of 17 percent of the average commuting time of employed workers. This is especially prevalent in non-metropolitan areas, and it also appears to depend on the size of the population of the area of residence. Our results suggest that there is a complex relationship between urban form and the commuting behavior of workers.
\end{abstract}

Keywords: Commuting; Urban cores; American Time Use Survey; Self-employed workers; Employed workers.

JEL Codes: R20, R41, J64.

\footnotetext{
* This paper was partially written while Jose Alberto Molina was Visiting Fellow at the Department of Economics of Boston College (US), to which he would like to express his thanks for the hospitality and facilities provided. This paper has benefited from funding from the Spanish Ministry of Economics (Project ECO2012-34828).

Correspondence to: Ignacio Gimenez Nadal, Department of Economic Analysis, Faculty of Economics, C/ Gran Via 2, $3^{\text {rd }}$ floor, 50005 - Zaragoza, Spain. Tel.: +34 876554683 Fax: +34 976761996 email: ngimenez@unizar.es
} 


\section{Introduction}

In this paper, we analyze the commuting behavior of workers in the United States, with a focus on the difference between employees and the self-employed. The analysis of commuting behavior is important for several reasons. Kahneman et al. (2004) and Kahneman and Krueger (2006) show that time spent in commuting ranks among the lowest activities in terms of the "instant enjoyment" obtained by individuals. There are also psychological costs associated with travel (Koslowsky et al., 1995; Evans et al., 2002; Kahneman et al., 2004), and commuting and health outcomes are negatively related (Walsleben et al., 1999; Jansen et al., 2003; Hämming et al., 2009; Hansson et al., 2011; Roberts et al., 2011). Furthermore, longer commutes are systematically associated with lower levels of well-being (Frey and Stutzer, 2008; Novaco and Gonzalez, 2009), and long commutes create stress for workers (Schaeffer et al., 1988; Hennessy and Wiesenthal, 1999; Wener et al., 2003; Gottholmseder et al., 2009; Novaco et al., 1990). Recent studies have shown that the time devoted to commuting has increased in recent years, in developed countries such as Germany (Gimenez-Nadal and Molina, 2014), the Netherlands (Susilo and Maat, 2007; Gimenez-Nadal and Molina, 2014) and the United States (Kirby and LeSage, 2009; McKenzie and Rapino, 2009; Gimenez-Nadal and Molina, 2016), leading to commuting time being a significant part of the total time devoted to the labor market (Kenworthy and Laube, 1999).

The commuting behavior of individuals has been extensively analyzed (see Ma and Banister, 2006, for a chronological review), and it has been incorporated into a range of theoretical models. According to job search models (van den Berg and Gorter, 1997; van Ommeren, 1998; Rouwendal, 2004), commuting is considered a source of labor mobility that allows workers to access geographically-dispersed labor markets without the need for migration (Cameron and Muellbauer, 1998). From the point of view of transport economics, commuters choose a mode of transport to minimize the monetary and opportunity costs of travel (DeSalvo and Huq, 1996). In urban economics, the focus is on household location, where commuting is generally assumed to confer disutility, and households are located to maximise the utility obtained from housing and all other goods (see the "monocentric city model" in Alonso (1964), Mills (1967), and Muth (1969), and the "polycentric city model" developed by Muller (1981), Garreau (1991), and Knox and McCarthy (2005)). 
In this paper we use the American Time Use Survey (ATUS) for the years 20032014 to examine the time devoted to commuting by employees and self-employed workers, with a focus on the difference between the two groups. We find that employees devote around 7.22 more minutes per day to commuting, compared to selfemployed workers, which is a difference of 17 percent of the average commuting time of employed workers. Our results are robust to selection into employment and into working from home, and to differences in the quality of jobs as measured by income. This difference in commuting time is present in individuals working at least 20 hours per week. Furthermore, when we take into account the geographical differentials across workers, we find that the difference in commuting time between the employed and the self-employed is present in the fringe zones of metropolitan areas, and in nonmetropolitan areas, but not in the core metropolitan areas. Furthermore, we find that this difference also depends on the size (i.e., population) of the area where workers are located. Thus, the difference in commuting time between the employed and the selfemployed does not exist in areas of greater employment density, and also depends on the size of the population of the area of residence, indicating the presence of a complex relationship between urban form and the commuting behavior of workers.

Our contribution to the literature is twofold. First, we contribute to the literature by offering up-to-date evidence of the commuting behavior of workers in the US, with a focus on location differences in commuting behavior. Following prior research on this topic (see Cropper and Gordon, 1991, Small and Song, 1992, Manning, 2003, and Rodriguez, 2004), we show that there is a complex relationship between urban form and the commuting behavior of US workers, which may be important for researchers and employers, and it warrants a more thorough investigation. Our results may also be of interest for policy makers, as transportation plans (e.g., highway construction, availability of public transport) may consider the geographical differences in commuting behavior. Second, we use information from a nationally-representative time use survey, which has been underused in the literature on commuting (National Travel Surveys have traditionally been used for the analysis of commuting patterns of households). Time is generally more accurate than distance, which presumably leads to a reduced error term (Small and Song, 1992; van Ommeren and Van der Straaten, 2008; Jara-Díaz and Rosales-Salas, 2015; Gimenez-Nadal and Molina, 2016), and thus the use of a time use survey can serve as a complement to National Travel Surveys (Kitamura 
and Fuji, 1997; Gimenez-Nadal and Molina, 2014; Gimenez-Nadal and Molina, 2016). There are alternative ways of looking at commuting (according to the effort/cost involved, the time spent, or the distance travelled), and this approach directly collects a number of aspects related to the cost of commuting, such as the condition and traffic density of roads and urban highways, among others, which may result in slower speeds, longer trip times, and increased vehicular queueing. Prior literature using the ATUS to analyze the commuting behavior of workers includes Yang and French (2013), Gimenez-Nadal, Molina and Velilla (2017), Kimbrough (2016), and Stone and Schneider (2016).

The rest of the paper is organized as follows. Section 2 describes the data, Section 3 describes our econometric strategy, Section 4 presents the results, and Section 5 lays out our main conclusions.

\section{Data and variables}

\subsection{Data and sample}

We use the 2003-2014 American Time Use Survey (ATUS) to measure the commuting time of workers in the US. Respondents are asked to fill out a diary summarizing episodes of the preceding day, and thus the ATUS provides us with information on individual time use, based on diary questionnaires in which individuals report their activities throughout the 24 hours of the day. The ATUS includes a set of activities, defined as the activity individuals were engaged in throughout the day, and thus we are able to add up the time devoted to any given reference activity (e.g., paid work, leisure, TV watching). The ATUS is administered by the US Bureau of Labor Statistics, and is considered the official time use survey of the country. More information can be found at http://www.bls.gov/tus/.

The advantage of time-use surveys over stylized questions, such as those included in the European Community Household Panel (ECHP), the British Household Panel Survey (BHPS), and the German Socio-Economic Panel (GSOEP), where respondents are asked how much time they have spent, for example, in the previous week, or normally spend each week, on any activity, is that diary-based estimates of time use are more reliable and accurate than estimates derived from direct questions (Juster and Stafford, 1985; Robinson, 1985; Bianchi et al., 2000; Bonke, 2005; Yee-Kan, 2008). Thus, in the same way that money-expenditure diaries have become the gold standard in 
the consumption literature, so have time-use diaries become the preferred method of gathering information about time spent on market work, non-market work, and leisure. Most studies documenting how individuals use their time are now based on these data sets (Aguiar and Hurst, 2007; Guryan et al., 2008; Ramey and Ramey, 2010; Sevilla, Gimenez-Nadal and Gershuny, 2012).

We restrict the sample used throughout our analysis to workers between the ages of 21 and 65 (inclusive). Furthermore, given that workers may have reported their activities during non-working days, thus having no commuting time that day, we restrict the analysis to working days, defined as those days when individuals devoted at least 60 minutes to market work activities excluding commuting. We additionally exclude those workers who reported no time in commuting during the day of the survey, which represents $12 \%$ of the self-employed in our initial sample. We finally exclude those observations that can be considered outliers. To that end, we have identified the outliers in multivariate data using the blocked adaptive computationally efficient outlier nominators algorithm proposed by Billor, Hadi and Velleman (2000).

Regarding the time devoted to commuting, we consider the time of "commuting to/from work", with the activity code "180501". Figure 1 shows the average time devoted to commuting, during the years of the survey, for the selected sample. We have added a linear trend based on the average values, to gain an idea of the trends in commuting time. We observe that commuting time has increased during the years of the survey, consistent with prior studies finding that commuting time in the US has increased (Kirby and LeSage, 2009; McKenzie and Rapino, 2009; Gimenez-Nadal and Molina, 2016). Furthermore, when we focus on the measurement of the difference in the time devoted to commuting between employees and the self-employed, Table 1 shows the average time devoted to commuting by employees (42.27 minutes) and the selfemployed (39.70 minutes) during their working days. We find a statistically-significant difference of -2.57 minutes between the self-employed and employees, representing a difference in commuting time of 5.95\%.

\subsection{Geographic information}

The ATUS includes several variables of the demographic location of individuals, following the US Census Bureau's categorization of metropolitan areas. The Census Bureau has a terminology for metropolitan areas and the classification of specific areas: 
a metropolitan area consists of a large population center and adjacent communities that have a high degree of economic and social interaction. Hence, the different metropolitan areas are highly comparable across time and individuals.

Three dimensions of the geographic location of individuals are relevant to our analysis. First, the ATUS includes a categorization of households as to whether they are in the central city within a metropolitan area, on the fringe of a metropolitan area (or just in a metropolitan area if no distinction is made), or in a non-metropolitan area. Some small metropolitan areas do not have a central city/outlying area distinction, so households in those areas are excluded from the analysis. We define three dummy variables as follows: metropolitan (central city within a metropolitan area), fringe metropolitan (fringe of a metropolitan area) and non-metropolitan. As shown in Table 1, employees have a greater probability of being in a metropolitan center, and thus a lower probability of being in a non-metropolitan area, with such differences being statistically significant at standard levels.

Second, the ATUS includes information about the Metropolitan Statistical Area (MSA) where the individuals are located. These metropolitan areas are counties or groups of counties centering on a substantial urban area, and they consist of a large population center and adjacent communities that have a high degree of economic and social interaction. The ATUS includes more than 30 MSAs. The MSA classification allows us to take into account the existence of differences in spatial structure across areas, and the fact that the employment structure of certain areas may be more amenable to self-employment. However, here we must highlight that the MSAs often cross state lines - e.g., New York (NY), Newark (NJ), and Bridgeport (CT) - and may include two or more cities within the same category, and thus this classification is not based on cities as units. In this sense, this MSA classification would therefore be an intermediate classification between state and city levels. Furthermore, we cannot compare employees and the self-employed within each MSA, because drawing comparisons or estimates for specific metropolitan areas may be problematic, given the small sample size in some of the MSAs.

Third, the ATUS includes information on the population size of the metropolitan (MSA) area in which workers are located, coded as follows: 1) Non metropolitan; 2) $100,000-249,999,3)$ 250,000-499,999, 4) 500,000-999,999, 5) 1,000,000-2,499,999, 6) 2,500,000-4,999,999, and 7) 5,000,000+. The MSAs are the same as those defined 
by the above classification. The population size of the area of residence may be relevant to the commuting behavior, as prior research has found that individuals in larger cities have longer commutes (Mieszkowski and Mills, 1993; Gordon, Kumar and Richardson, 1989; Kahn, 2000).

Table 1 shows the summary statistics for metropolitan/non-metropolitan status and the size of the MSA of residence, for employees and the self-employed. In general, we observe that the self-employed have a higher probability of living in non-metropolitan areas, and in areas with a smaller population $(17.5 \%$ and $14.9 \%$ of the self-employed and employees of our sample, respectively, live in a non-metropolitan area), while they have a lower probability of living in the center of metropolitan areas $(20 \%$ and $23.4 \%$ of the self-employed and employees of our sample, respectively, live in a metropolitan center). Regarding the size of the population, a greater proportion of self-employed workers live in areas with 100,000-249,999 inhabitants (1\% more), and a lesser proportion of self-employed workers live in areas of 1,000,000-2,499,999 (1.8\% fewer) and 2,500,000-4,999,999 inhabitants (1.3\% fewer). Thus, there are differences in the geographic characteristics of the area of residence between the self-employed and employees, which may explain why the self-employed have shorter commutes then employees.

\section{Econometric strategy}

\subsection{Econometric model}

We estimate OLS regressions on the time devoted to commuting, a model that has often been applied in prior research using time use data on commuting (Gimenez-Nadal and Molina, 2014; 2016). The existing literature on the methodology needed in the treatment of time use data concludes that results with the use of OLS and Tobit models are similar (Frazis and Stewart, 2012; Gershuny, 2012; Foster and Kalenkoski, 2013; Gimenez-Nadal and Molina, 2014). The statistical model is as follows: for a given individual "i", let $C_{i}$ represent the daily hours individual "i" devotes to commuting, let Employee $_{i}$ be a dummy variable to indicate whether respondent "i" is an employee (1) or not $(0)$, let $X_{i}$ be a vector of socio-demographic and job characteristics, and let $\varepsilon_{i}$ be random variables that represent unmeasured factors. We estimate the following equation:

$$
C_{i}=\alpha+\beta * \text { Employe }_{i}+\gamma * X_{i}+\varepsilon_{i}
$$


where $C_{i}$ represents the time devoted to commuting by worker "i". Since the variable of commuting time does not follow a normal distribution, we have transformed the variable to its $\log$ form. Figure 2 shows the distribution of the transformed variable of commuting time, for both employees and the self-employed, using kernel-density distributions. We can observe that the transformed variable concentrates its values around 3.5 for the two groups, and the two tails resemble the shape of a normal distribution. Furthermore, we have corrected the standard errors to obtain robust standard errors, so that errors are homoskedastic.

\subsection{Socio-demographic and job characteristics}

In our analysis, we consider various characteristics of workers that may have a direct relationship with the time devoted to commuting. Given prior research showing that men and women have different commutes (Gimenez-Nadal and Sevilla, 2011; 2012; Gimenez-Nadal and Molina, 2014, 2016), we take into account the gender of the worker ( $1=$ male, $0=$ female). Other variables that may affect the time devoted to commuting by workers (see Gimenez-Nadal and Molina, 2016, for a review) are age of respondents, education, race, being a citizen of the US, whether the respondent lives in couple, respondent couple's labor status, the number of children in the household, family size, and the number of working hours per week (self-reported, retrospective method).

For education, we consider three education levels: primary education (less than high school diploma), secondary education (high school diploma), and university education (more than high school diploma), and we define three dummies. In the case of race, we define a dummy variable considering the respondent being white (1) or not (0). The same applies for the variable of citizenship; we create a dummy variable considering the respondent having US citizenship (1) or not (0). We also identify individuals living in couple, or not, and those whose partner is working, with two dummy variables. The variable for the presence of children refers to a dummy variable indicating whether there are children under 18 in the household (1) or not (0). Primary education is chosen as the education level of reference.

The ATUS allows us to compute the mode of transport of all the commuting episodes. Respondents report their commuting episodes, together with whether the commuting episode was done by car, public transport, etc. Thus, we compute the 
percentage of commuting that is done via different modes of transport, measured as the percentage of the total time in commuting. For example, for commuting time by car we sum the commuting time using this mode of transport, and we divide the sum by the total time devoted to commuting. We define the following modes of transport: private vehicle (car, truck, or motorcycle (driver); car, truck, or motorcycle (passenger)), active commuting (walking, bicycle), public transport (bus, subway/train, boat/ferry, taxi/limousine service), and other transport (airplane, other mode of transportation).

Table 1 shows that, compared to employees, self-employed workers are relatively older, have a greater probability of being male and a relatively higher level of education (i.e. a higher proportion of workers with university education), and a higher proportion are white and US citizens. Furthermore, self-employed workers have, in comparison to employees, a greater probability of living in couple, and thus of having a working partner. Also, self-employed workers have statistically significant longer weekly working hours than employees. Regarding the mode of transport, the main means of transport reported by workers is private vehicle, followed by active commuting and public transport, although there are differences between employees and the selfemployed, as the former have a higher proportion using private vehicles. Employees also appear to do more active commuting and commuting by public transport, which may indicate that employees have longer commutes in comparison to the self-employed. Thus, given the heterogeneity of the two groups of workers, which may condition the observed differences in commuting time, it is important to control for the sociodemographic characteristics.

We also take into account in our analysis the occupation and industry of workers. Most theoretical models assume that workers are homogeneous, in the sense that workers are directly comparable. However, there may be certain industries and occupations where it is more difficult to run a business, and thus the characteristics of workers in those sectors may differ more than in others. Furthermore, prior research has shown a relationship between occupations and commuting (Hanson and Johnston, 1985; Gordon, Kumar and Richardson, 1989; Hanson and Pratt, 1995), as for instance, femaledominated occupations are more evenly distributed compared to men, and thus women may choose jobs closer to home. For this reason, and given that we have information on the occupation and industry, we define the occupation and industry of workers. In doing so, we consider the classification used by the ATUS dataset, that aggregates the industry 
and occupation codes into 14 and 11 categories, respectively. For industry, the following categories are defined: Agriculture, forestry, fishing, and hunting; Mining; Construction; Manufacturing; Wholesale and retail trade; Transportation and utilities; Information; Financial activities; Professional and business services; Educational and health services; Leisure and hospitality; Other services; Public administration; and Armed Forces. For occupation, the following categories are defined: Management, business, and financial; Professional and related; Service; Sales and related; Office and administrative support; Farming, fishing, and forestry; Construction and extraction; Installation, maintenance, and repair; Production; Transportation and materials moving; and Armed Forces.

Table 1 shows that $27.0 \%$ of the self-employed work in management and business occupations, with this having the highest percentage of self-employed workers, followed by sales (17.3\%), professional occupations (16.9\%), services (15.1\%), construction $(11.7 \%)$, installation $(3.4 \%)$, transportation $(3.2 \%)$, office and administration (2.6\%), production occupations $(2.3 \%)$ and farming and fishing $(0.4 \%)$. On the other hand, the largest number of employees work in professional occupations (19.6\%), followed by management and business (16.9\%), services $(15.0 \%)$, office and administration (13.1\%), sales (11.9\%), production $(7.8 \%)$, transportation $(6.1 \%)$, construction (4.6\%), installation (4.1\%) and, finally, farming and fishing (0.9\%). These differences between the two groups are all significant at the $99 \%$ level (or the $95 \%$ level in the case of installation occupations), except for services. These differences in the percentage of workers in each occupation show that the self-employed are more heterogeneously distributed across occupations than are employees, consistent with the existing literature (Lee, 1999; Hamilton, 2000; Molina et al., 2016).

Research has shown a relationship between wages and individual commuting behavior (Van Ommeren, van den Berg and Gorter, 2000; Timothy and Wheaton, 2001; Rupert, Stancanelli and Wasmer, 2009). However, the inclusion of wages in the analysis of commuting time may lead to endogeneity problems, since the inclusion of income in models predicting commuting time introduces the possibility of an endogenous relationship, where in those with burden some commutes are compensated for them. Thus, and to the extent that education has been found to have a positive relationship to commuting time, we use education as a proxy for earnings. 


\subsection{Differences in commuting by geographic characteristics}

In the previous Section, we reported that employees and self-employed workers have different geographic characteristics, which may mean that the difference in the time devoted to commuting by the employed and the self-employed is different due to geographic differences across groups of workers. As first evidence on this issue, we compute the time devoted to commuting by employees and the self-employed according to the different geographic characteristics included in the ATUS, in order to see whether the difference between the employed and self-employed differs with the geographic characteristics of workers. Table 2 shows the commuting time of employees and the self-employed, the value of the difference between the two groups, and the p-value of a t-test of this difference, according to the metropolitan status, and the size of the population of the MSA.

First, we observe that, while the difference in commuting between the employed and the self-employed is not statistically significant in the center of metropolitan areas, it is statistically significant in the fringe zones of metropolitan areas, and in nonmetropolitan areas. In particular, we find that employees devote 2.5 more minutes per day to commuting, which represents $6.15 \%$ and $8.02 \%$ of commuting time of the selfemployed in the fringe zones of metropolitan areas and in non-metropolitan areas, respectively. Furthermore, this difference is statistically significant in highly-populated areas, as employed workers devote 2.41 and 3.51 more minutes per day to commuting than self-employed workers in areas with 1,000,000-2,499,999 and 5,000,000+ inhabitants, respectively, which represents $6.11 \%$ and $6.84 \%$ of commuting time of the self-employed in these areas. Thus, we find that the difference in commuting between the employed and the self-employed is not present in all geographical areas, but it is especially important in non-metropolitan areas, or in highly-populated areas.

Given that we find the differences in commuting time between the employed and the self-employed vary by the geographic location, we also estimate the following equation:

$$
C_{i}=\alpha+\beta^{*} \text { Employee }_{i}+\gamma^{*} X_{i}+\eta * \text { Geographic }_{i}+\varepsilon_{i}
$$

where $C_{i}$ represents the $(\log )$ time devoted to Commuting by worker "i". The vector $X_{i}$ includes the set of socio-demographic and job characteristics described in Section 2.2

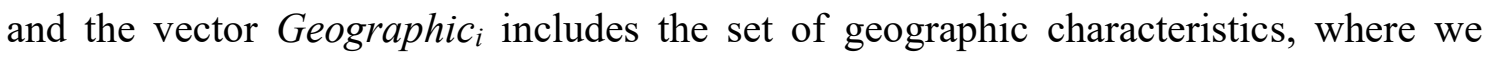
include whether the respondents live in a metropolitan area, or not (ref.: central city 
within a metropolitan area), and the size of the metropolitan area (ref.: Nonmetropolitan).

\section{Results}

\subsection{Basic results}

If we estimate differences in commuting between the employed and the self-employed according to Equation (1), we find that the coefficient for employees is positive and statistically significant at standard levels, indicating that employees spend comparatively more time in daily commuting than do the self-employed. In particular, we find that employees spend 7.22 more minutes per day to commuting than their selfemployed counterparts, which represents a difference of $17 \%$ of the average commuting time of employed workers. As a result, we find that employed workers devote comparatively more time to commuting than the self-employed in the US.

In line with Table 1, the prior literature on self-employment suggests that selfemployed jobs are very heterogeneous (Lee, 1999; Hamilton, 2000; Molina et al., 2016). This includes well-paid attractive jobs, and jobs that are a "last resort" (marginal jobs) for individuals who cannot actually have an employee job. This may lead to the self-employed and the employed having differences in earnings, leading to differences in commuting behavior (Van Ommeren, van den Berg and Gorter, 2000; Timothy and Wheaton, 2001; Rupert, Stancanelli and Wasmer, 2009). Despite that we control for occupation fixed effects, such differences may not be captured in our econometric specification, and thus we test the robustness of our results, considering the income differences between the employed and the self-employed.

In doing so, we match employed and self-employed workers according to their household income. Although household income is not a direct measure of individual earnings, it may be considered as a proxy, as higher household income may be an indicator of higher earnings of the household members. In the ATUS, the information on household income refers to the combined income of all family members during the last year and includes wages, net income from business, farm or rent, pensions, dividends, interest, Social Security payments, and any other money income received by family members who are 15 years of age or older. Household income is coded with income brackets, from values 1 (e.g., Less than 5,000\$) to 16 (e.g., $\$ 150,000$ and over). 
We create three income categories, according to the position of each observation in the income distribution: the group of workers in the bottom $25 \%$ of the income distribution (i.e., low income, $<\$ 25,000$ ), the group of workers between $25 \%$ and $75 \%$ of the income distribution (medium income, \$25,000-\$75.000), and the group of workers in the top $25 \%$ of the income distribution (high income, $>\$ 75,000$ ). Columns (2), (3) and (4) of Table 3 shows the results of estimating Equation (1) for the three income groups, and we find that the difference in commuting time between the employed and self-employed is of the expected sign and statistically significant in the three groups. Furthermore, the difference in commuting time between the employed and the self-employed increases as household income increases, which may indicate that in jobs associated with low levels of income the difference in commuting time is smaller than in jobs associated with high levels of income, and thus the difference in commuting time in "low quality" jobs is smaller than the difference in commuting time in "high quality" jobs.

Additionally, Hamermesh and Stancanelli (2015) show that many Americans work night-time and weekend jobs, more than do Europeans, suggesting that working schedules may be more flexible in the US than in Europe, and also that Americans work longer hours than do Europeans. Thus, the difference in commuting between the employed and self-employed may depend on the number of work hours. We divide the sample according to the number of hours per week reported. Our groups are based on the evidence shown by Hamermesh and Stancanelli (2015) that there is a comparatively higher proportion of workers working 45 or more hours per week in the US than in European countries, and that working 45 or more hours per week is positively related with working during the weekend and/or at night. Given this evidence, we define three groups of workers according to the number of hours per week they reported: those working less than 20 hours per week (short hours, 8.3\% of workers), those working between 20 and 44 hours per week (middle hours, 58.6\% of workers), and those working 45 or more hours per week (long hours, $33.1 \%$ of workers).

Results for the group of workers working short hours, middle hours, and long hours are shown in Columns (5), (6) and (7) of Table 3, respectively. We observe that the difference in commuting time between the employed and the self-employed is statistically significant for workers with middle hours and long hours. Thus, differences between the employed and the self-employed in the time devoted to commuting varies 
according to the number of work hours, with the group of workers reporting long hours showing the greatest difference.

Finally, we have tested the robustness of our results considering sample selection issues. Prior studies have shown that the observed commute may overestimate the desired or ideal commute, being conditional on employment (Hamilton, 1982; Small and Song, 1992). Thus, we consider sample selection issues, in a similar framework, where differences in wages are estimated (Heckman, 1979). We estimate commuting differences between the employed and the self-employed, where employment is considered using a Heckman selection model where gender and family composition characteristics (e.g., living in couple, labour status of the couple, respondent with children, and the size of the family) are used to control for participation into employment. Results (Columns (1) and (2) of Table A1) are consistent with the consideration of sample selection issues. Furthermore, the inclusion of non-commuters in our sample does not change our conclusions. Column (3) of Table A1 in the appendix shows the results of estimating with a sample including non-commuters on the day of the survey, and where a Tobit model is used to control for participation into commuting on the day of the survey. The difference in commuting time between the employed and the self-employed is maintained. Thus, our results are robust to sample selection issues, despite that employed workers have a lower probability of non-commuting during their working days (Column 4 of Table A1).

\subsection{Results considering the geographic location}

Table 4 shows the results of estimating Equation (2) on the time devoted to commuting (see Table A2 for results regarding the socio-demographic controls). Column 1 shows the results of estimating Equation (2) including geographic controls (Geographic model), and Column 2 shows the results of including interactions between employee status and geographic controls (Interaction model). We include interactions between the variable of employee status and geographic characteristics because we report that the difference in the time devoted to commuting between the employed and the selfemployed varies by location.

When we include geographic controls, we observe that the coefficient for employees is positive and statistically significant at standard levels, and very close to the coefficient obtained from the General model. Thus, our results are consistent to the 
inclusion of geographic controls. We observe that those living in the fringe of metropolitan areas have longer commutes, and those living in larger cities also have longer commutes, as the coefficients for 500,000 inhabitants or more are positive and statistically significant, increasing with the size of the area. The results may be interpreted as that those living in lower-density environments, and those in larger cities, have longer commutes, which has been well-established in the literature (White, 1988; Hamilton, 1989; Gordon, Kumar and Richardson, 1989; Kahn, 2000; Van Ommeren and Van der Straaten, 2008). However, here we face a limitation in the data, as we do not know distances, and thus these differences may be due to several spatial processes, such as traffic congestion. Furthermore, such differences may be due to differences in the mode of transport, although the fact that we control for the mode of transport in our regressions makes this point unlikely. (Getting deeper into that issue through alternative measures of commuting, such as distance as a dependent variable, would be interesting.)

When we interact employee/self-employed status with the geographic characteristics of workers (Interaction model), we find that the difference in commuting time between the employed and the self-employed is present in the fringe zones of metropolitan areas, and in non-metropolitan areas, but not in the core metropolitan areas. Furthermore, we find that this difference depends on the size (population) of the area where workers are located. Thus, we observe that the difference in commuting time between the employed and the self-employed varies with the geographical characteristics of workers' residence. However, we cannot provide any explanation for these results, given the nature of the data. Perhaps such differences are explained by differences in search imperfections (smaller areas have fewer search imperfections and thus lower or no differences in commuting). But the results shown here may be a result of the measure of commuting used. To the extent that we have no information on travel distance, it could also be that the self-employed and employees have similar travel times in some areas, but different travel distances. Also, it could be that, in those cases where there exists a difference regarding time between the two groups of workers, actual distances travelled among the privately employed and the self-employed are not all that different. Van Ommeren and Van der Straaten (2008) suggest that the self-employed travel faster, as there are differences between the two groups in the choice of mode of transport. Thus, differences in the mode of transport between employees and the self-employed would help to explain these differences. 


\subsection{Other results}

For the rest of the controls included in the regressions, we find that age has an inverted U-shaped relationship with commuting time, with the maximum commuting time being reached at the age of 46 . The gender of the individual is also important for the time devoted to commuting, as males report more time devoted to commuting, consistent with prior research. Being white and being a US Citizen is related to less commuting time. Having children is negatively related to the time devoted to commuting, which is consistent with the Household-Responsibilities Hypothesis (Gimenez-Nadal and Molina, 2016). The usual number of hours of work per week has a positive relationship to commuting, while those who live in couple tend to do more commuting because they often need more income, so they look for more specialized jobs (Flowerdew, 1992; Green, 1997; McQuaid and Chen, 2012). On the contrary, for a couple where both members have an active labor status, the relationship to commuting time is negative. Finally, the use of public transport or private vehicle is related to an increase in the time devoted to commuting, in relation to alternative methods of transport, such as active commuting.

The observed $R^{2}$ in the three models is quite low. When we compare our results with Gimenez-Nadal and Molina (2016), whose authors use time-use data from the Netherlands, we observe that the $R^{2}$ is well below 0.25 , and thus our results are in line. Other studies have used other sources of data and also find a low level of explained variance (White, 1986; Rouwendal and Rietveld, 1994; Benito and Oswald, 1999; Van Ommeren et al., 1999, Van Ommeren and van der Straaten; 2008), which suggests that commuting is mainly an outcome of a stochastic process, in which lack of complete information plays an important role.

\section{Conclusions}

This paper analyses the commuting behavior of workers in the US for the period 20032014, focusing on the differences in commuting time between employed and selfemployed workers. We find that employees spend comparatively more time in daily commuting than do the self-employed. In particular, we find that employees spend 7.22 more minutes per day to commuting than their self-employed counterparts, which represents a difference of $17 \%$ of the average commuting time of employed workers. 
When we incorporate the geographic dimension in the analysis, we find that this difference is present in the fringe zones of metropolitan areas, and in non-metropolitan areas, but not in core metropolitan areas. This difference also depends on the size (population) of the area where workers are located, indicating that congestion and distance are positively related to commuting time. Thus, we observe that the difference between employed and self-employed workers in the time devoted to commuting varies with the geographical characteristics of workers' residence, suggesting that there is a complex relationship between urban form and the commuting behavior of workers that is worthy of analysis. However, we cannot give a complete view of the issue, as we do not have information on distance, and the evidence presented here may serve as a first step to explore these differences in more detail.

We hope that our results will stimulate further research on the topic of commuting behavior. Theoretical, as well as further empirical, research is needed to shed light on the question of how commuting behavior changes over time, and to determine how new infrastructures (e.g., highways, metro lines...) contribute to this behavior. It may be that policies aimed at promoting rental housing favor the reduction of commuting, as location costs would be reduced and workers would tend to locate closer to the urban centers. Here, we have the case of Spain, a country with a high propensity to own housing property, and where young individuals are given a fixed monthly amount of money for rental housing, which allows them to "leave the nest" and set up their own house. It may be of interest to see if this measure would be useful, given that the majority mode of transport is by private car and the commute is a significant emitter of greenhouse gases. Encouraging the use of public transport and investing in it would significantly reduce such emissions (Chan et al., 1999; Chertok et al., 2004; Karanasiou et al., 2014) in certain areas, although in some other areas, access by public transport may be problematic and would be counter-productive, given the need to allocate buses on an individual basis. The study of the environmental impact of commuting is a field that has been largely overlooked.

One important limitation in our analysis is that we cannot control for the unobserved heterogeneity of individuals, which is important in this context as unobserved factors (e.g., preferences, previous experience, parents' background) may condition decisions about what type of employment workers want, and their associated commuting behavior. Van Ommeren and Van der Straaten (2008) argue that selection 
into self-employment is an important issue, since there may be unobserved factors related to both the decision to be self-employed (vs. employed) and how much time is spent in daily commuting. One way to overcome this limitation is to use data with a panel structure. Alternative datasets with a panel structure, such as the British Household Panel Survey, The German Socio-Economic Panel, and the Panel Study of Income Dynamics, all provide information on both commuting behavior and employment, which could be used to investigate this topic.

\section{REFERENCES}

Aguiar, M. and E. Hurst(2007). "Measuring trends in leisure: the allocation of time over five decades," Quarterly of Journal Economics 122, 969-1007.

Alonso, W. (1964). “Location and Land Use,” Harvard University Press, Cambridge.

Benito, A., and A.J. Oswald (1999). "Commuting in Great Britain in the 1990s," University of Warwick.

Van den Berg, G.J., and C. Gorter (1997). “Job search and commuting time," Journal of Business and Economic Statistics 15, 269-281.

Bianchi, S., M. Milkie., L. Sayer and J.P. Robinson (2000). "Is anyone doing the housework? Trends in the gender division of household labor," Social Forces 79, $191-228$.

Billor, N., A.S. Hadi, and P.F. Velleman (2000). "BACON: blocked adaptative computationally efficient outlier nominators," Computational Statistics \& Data Analysis 34(3), 279-289.

Bonke, J. (2005). "Paid work and unpaid work: Diary information versus questionnaire information," Social Indicators Research 70, 349-368.

Cameron, G. and J. Muellbauer (1998). "The housing market and regional commuting and migration choices," Scottish Journal of Political Economy 45, 420-446.

Chan, L.Y., Chan, C.Y. and Y. Qin (1999). "The effect of commuting microenvironment on commuter exposures to vehicular emission in Hong Kong,"Atmospheric Environment, 33(11), 1777-1787. 
Chertok, M., Voukelatos, A., Sheppeard, V. and C. Rissel (2004). "Comparison of air pollution exposure for five commuting modes in Sydney-car, train, bus, bicycle and walking,"Health promotion journal of Australia, 15(1), 63-67.

Cropper, M.L. and Gordon, P. (1991). "Wasteful Commuting: A Re-examination," Journal of Urban Economics 29, 2-13.

DeSalvo, J.S., and M. Huq (1996). "Income: residential location, and mode choice," Journal of Urban Economics 40, 84-99.

Evans, G.W., R.E Wener and D. Phillips (2002). "The morning rush hour: predictability and commuter stress," Environment and Behavior 34, 521-530.

Flowerdew, R. 1992. "Labour market operation and geographical mobility," in A.G. Champion and A.J. Fielding (eds), Migration Processes and Patterns Volume 1: Research Progress and Prospects. London: Belhaven Press, pp. 77-101.

Foster, G. andC. Kalenkoski(2013).“Tobit or OLS? An empirical evaluation under different diary window lengths," Applied Economics 45, 2994-3010.

Frazis, H., and J. Stewart (2012). "How to Think About Time-Use Data: What Inferences Can We Make About Long- and Short-Run Time Use from Time Use Diaries?" Annals of Economics and Statistics 105/106, 231-246.

Frey, B.S., and A. Stutzer (2008). Stress that Doesn”t Pay: The Commuting Paradox," Scandinavian Journal of Economics 110, 339-366

Garreau, J. (1991). Edge City: Life on the New Frontier. Doubleday, New York.

Gershuny, J. (2012). “Too Many Zeros: A Method for Estimating Long-term Time-use from Short Diaries," Annals of Economics and Statistics 105/106, 247-270.

Getis, A. (1969). "Residential location and the journey from work," Proceedings of the Association of American Geographers 20, 55-59.

Gimenez-Nadal, J.I. and J.A. Molina (2014). "Commuting Time and Labour Supply in the Netherlands: A Time Use Study," Journal of Transport Economics and Policy 48, 409-426.

Gimenez-Nadal, J.I. and J.A. Molina (2016). "Commuting Time and Household Responsibilities: Evidence using Propensity Score Matching," Journal of Regional Science 56(2): 332-359. 
Gimenez-Nadal, J.I., J.A. Molina and J. Velilla (2017). "Spatial distribution of US employment in an urban wage-efficiency setting," Journal of Regional Science (Forthcoming).

Gimenez-Nadal, J.I., and A. Sevilla (2011). "The Time-Crunch Paradox," Social Indicators Research 102: 181-196.

Gimenez-Nadal, J.I. and A. Sevilla (2012). "Trends in time allocation: a cross-country analysis," European Economic Review 56, 1338-1359.

Gordon, P., A. Kumar and H. Richardson (1989). "Gender differences in metropolitan travel behavior," Regional Studies 23: 499-510.

Gottholmseder, G., K. Nowotny, G.J.Pruckner and E. Theurl (2009). "Stress perception and commuting," Health Economics 18, 559-576.

Green, A. E. (1997). "A question of compromise? Case study evidence on the location and mobility strategies of dual career households," Regional Studies, 31(7), 641-657.

Guryan, J., E. Hurst, and M. Kearney (2008). "Parental education and parental time with children," Journal of Economic Perspectives 22: 23-46.

Hamermesh, D.S. and E. Stancanelli (2015). "Long workweeks and strange hours," ILR Review 68(5), 1007-1018.

Hamilton, B.H. (2000). "Does entrepreneurship pay? An empirical analysis of the returns of self-employment," Journal of Political Economy 108, 604-631.

Hamilton, B.W. (1982). "Wasteful commuting," Journal of Political Economy 90, 1035-1053.

Hamilton, B.W. (1989). "Wasteful commuting again,” Journal of Political Economy 97, 1497-1504.

Hämming, O., F. Gutzwiller and G. Bauer (2009). "Work-life conflict and associations with work and nonwork-related factors and with physical and mental health outcomes: a national representative cross-sectional study in Switzerland," BMC Public Health 9, 435.

Hansson, E., K. Mattisson, J. Björk, P. Östergren and K. Jakobsson (2011). "Relationship between commuting and health outcomes in a cross-sectional population survey in southern Sweden,” BMC Public Health11, 834. 
Hanson, S. and I. Johnston (1985). "Gender differences in work trip lengths: Implications and explanations," Urban Geography 6: 193-219.

Hanson, S. and G. Pratt (1995). Gender work and space. International Studies of Women and Place. London: Routledge.

Heckman, J.J.(1979). "Sample selection bias as a specification error," Econometrica47(1), 53-161.

Hennessy, D.A., and D.L. Wiesenthal (1999). "Traffic congestion, driver stress, and driver aggression," Aggressive Behavior 25, 409-423.

Jansen, N.W.H., I.J. Kant, T.S. Kristensen and F.J.N. Nijhuis (2003). “Antecedents and Consequences of Work-Family Conflict: A Prospective Cohort Study," Journal of Occupational and Environmental Medicine 45, 479-491.

Jara-Díaz, S. and J. Rosales-Salas (2015). "Understanding time use: Daily or weekly data?" Transportation Research Part A: Police and Practice 76, 38-57.

Juster, T. and F. Stafford (1985). Time, Goods, and Well-Being. Ann Arbor, MI: Institute for Social Research.

Kahn, M.E. (2000). “The environmental impact of suburbanization," Journal of Policy Analysis and Management, 569-586.

Kahneman, D. and A.B. Krueger (2006). "Developments in the Measurement of Subjective Well-Being," Journal of Economic Perspectives 20, 3-24.

Kahneman, D., A.B. Krueger, D. Schkade, N. Schwarz and A. Stone (2004). "A Survey Method for Characterizing Daily Life Experience: The Day Reconstruction Method,"Science 3, 1776-1780.

Karanasiou, A., Viana, M., Querol, X., Moreno, T. and F. de Leeuw (2014). “Assessment of personal exposure to particulate air pollution during commuting in European cities-Recommendations and policy implications,"Science of the Total Environment, 490, 785-797.

Kenworthy, J.R., and F.B. Laube (1999). "Patterns of automobile dependence in cities: an international overview of key physical and economic dimensions with some implications for urban policy," Transportation Research Part A 33, 691-723. 
Kimbrough, G. (2016). "Measuring commuting in the American Time use Survey. University of North Carolina Working Papers15-02.

Kirby, D.K. and J.P. LeSage(2009)."Changes in commuting to work times over the 1990 to 2000 period," Regional Science and Urban Economics 39, 460-471.

Kitamura, R., and S. Fuji (1997). "Time-use data, analysis and modeling: toward the next generation of transportation planning methodologies," Transport Policy 4, $225-235$.

Knox, P.L., and L. McCarthy (2005). Urbanization: An Introduction to Urban Geography, Second edn, Prentice Hall, Englewood Cliffs, NJ.

Koslowsky, M., A. Kluger and Reich (1995). Commuting Stress: Causes, Effects and Methods of Coping. Plenum, New York.

Lee, A.T. (1999). "Empirical studies of self-employment," Journal of Economic Surveys 13(4), 381-416.

Mills, E.S. (1967). "An aggregative model of resource allocation in a metropolitan area," American Economic Review 57, 197-210.

Ma, K.M. and D. Banister (2006).“Excess commuting: a critical review," Transport Reviews 26, 749-767.

McQuaid, R. W., and T. Chen (2012). “Commuting times - The role of gender, children and part-time work," Research in Transportation Economics, 34(1), 66-73.

Manning, A. (2003)."The real thin theory: monopsony in modern labormarkets," Labour Economics 10, 749-767.

Mieszkowski, P., and E.S. Mills (1993). "The Causes of metropolitan Suburbanization," The Journal of Economic Perspectives 7(3), 135-147.

Muth, R.F. (1969). Cities and Housing: The Spatial Pattern of Urban Residential Land Use. University of Chicago Press, Chicago, IL.

Muller, P.O. (1981). Contemporary Suburban America. Prentice Hall, NJ.

McKenzie, B., and M. Rapino (2009). “Commuting in the United Stated: 2009," U.S. Department of Commerce, Economics and Statistics Administration, U.S. CENSUS BUREAU. 
Novaco, R.W., and O.I. Gonzalez (2009). Commuting and Well-being. In Y. AmichaiHamburger (Ed.), Technology and Psychological Well-Being (pp. 174-205). Cambridge University Press, Cambridge, U.K.

Novaco, R.W., D. Stokols and L. Milanesi (1990). "Objective and subjective dimensions of travel impedance as determinants of commuting stress," American Journal of Community Psychology 18, 231-257.

Van Ommeren, J. (1998). "On-the-job search behavior: the importance of commuting time," Land Economics 74, 526-540.

Van Ommeren, J., Rietveld, P., and P. Nijkamp (1999). "Job moving, residential moving and commuting: a search perspective," Journal of Urban Economics 46, 230-253.

Van Ommeren, J., Van der Bergh, G.J., and C. Gorter (2000). "Estimamting the marginal willingness to pay for commuting," Journal of Regional Science 40(3), 541-563.

Van Ommeren, J.N. and J.W. Van der Straaten(2008).“The effect of search imperfections on commuting behavior: Evidence from employed and self-employed workers," Regional Science and Urban Economics 38, 127-147.

Ramey, G. and V.A. Ramey (2010). “The Rug Rat Race,” NBER Working Paper Series 15284, National Bureau of Economic Research.

Robinson, J.P. (1985). "The validity and reliability of diaries versus alternative time use measures," in Time, goods, and well-being: Juster and Stafford (eds). Ann Arbor, MI: The University of Michigan, pp 33-62.

Roberts, J., R. Hodgson and P. Dolan (2011). “It's driving her mad: Gender differences in the effects of commuting on psychological health," Journal of Health Economics 30, 1064-1076.

Rodriguez, D.(2004).“Spatial choices and excess commuting: a case study of bank tellers in Bogota, Colombia," Journalof Transport Geography 12, 49-61.

Rouwendal, J. (2004). "Search theory and commuting behavior," Growth and Change $35,391-417$. 
Rouwendal, J., and P. Rietveld (1994). "Changes in commuting distances of Dutch households," Urban Studies 31(9), 1545-1557.

Rupert, P., E. Stancanelli and E. Wasmer (2009). "Commuting, wages and bargaining power," Annals of Economics and Statistics, 201-220.

Schaeffer, M., S. Street, J. Singer and A. Baum (1988). "Effects of control on the stress reactions of commuters.” Journal of Applied Social Psychology 18, 944-957.

Sevilla, A., J.I. Gimenez-Nadal, and J. Gershuny (2012). "Leisure Inequality in the United States: 1965-2003," Demography 49(3), 939-64.

Small, K. and S.Song (1992)."Wasteful commuting: a resolution," Journal of Political Economy 100, 888-898.

Stone, A.A. and S. Schneider (2016).“Commuting episodes in the United States: their correlates with experiential well being from the American Time Use Survey," Transportation Research Part F: traffic psychology and behavior 42, 117-124.

Susilo, Y.O. and K. Maat (2007). "The influence of built environment to the trends in commuting journeys in the Netherlands," Transportation 34, 589-609.

Timothy, D., and W.C. Wheaton (2001). "Intra-urban wage variation, employment location, and commuting times," Journal of Urban Economics 50(2), 338-366.

Molina, J.A., J. Velilla and R. Ortega (2016). "The decision to become an entrepreneur in Spain: The role of the household finances," International Journal of Entrepreneurship 20(1), 57-73.

Walsleben, J.A., R.G. Norman, R.D. Novak, E.B. O”Malley, D.M. Rapoport and K.D. Strohl (1999). “Sleep Habits of Long Island Rail Road Commuters,” Sleep 22,728734.

Wener, R.E., G.W. Evans, D. Phillips and N. Nadler (2003). "Running for the 7:45: the effects of public transit improvements on commuter stress," Transportation 30, 203-220.

White, M.J. (1986). "Sex differences in urban commuting patterns," American Economic Review 76, 368-372.

White, M.J.(1988). "Urban commuting journeys are not "wasteful"," Journal of Political Economy 96, 1097-1110. 
Yang, J. and S. French (2013). "The travel-obesity connection: Discerning the impacts of commuting trips with the perspective of individual energy expenditure and time use," Environment and Planning B: Planning and Design 40(4), 617-629.

Yee-Kan, M. (2008). "Measuring Housework Participation: The Gap Between "Stylised" Questionnaire Estimates and Diary-Based Estimates," Social Indicators Research 86, 381-400. 
Figure 1.

Average commuting time, by year

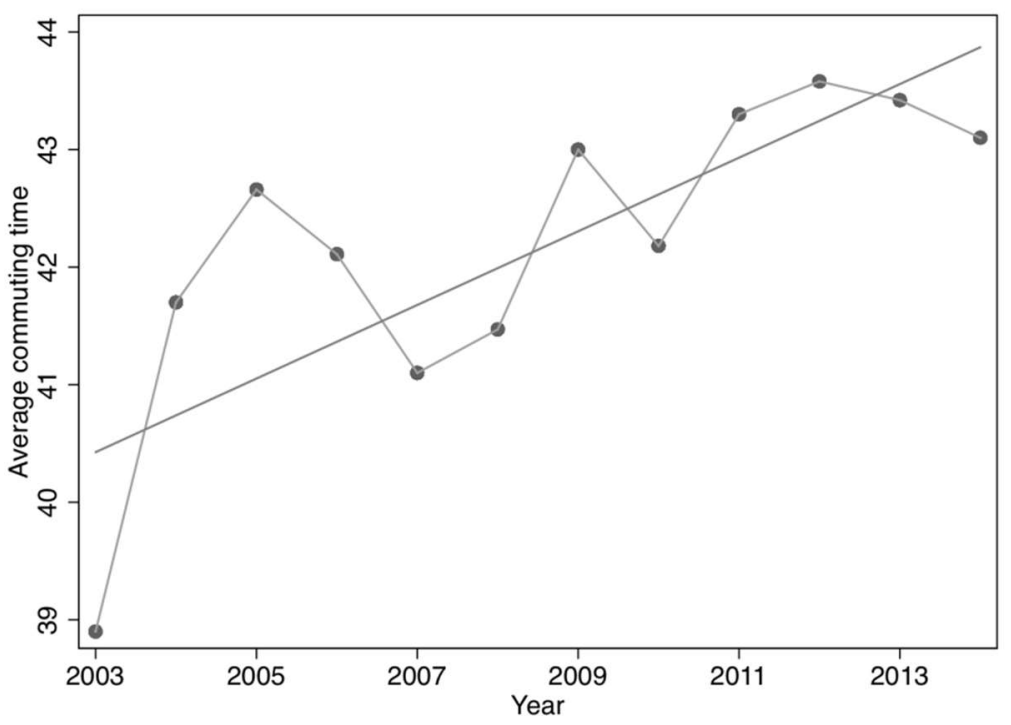

Note: The sample is restricted to individuals between 21 and 65 , who are not students and are not retired, working as self-employed or employed, and who work and commute on the diary day, from the ATUS 20032014. Commuting time is measured in hours per day. 
Figure 2

K-density distributions of log of commuting times, by employment status

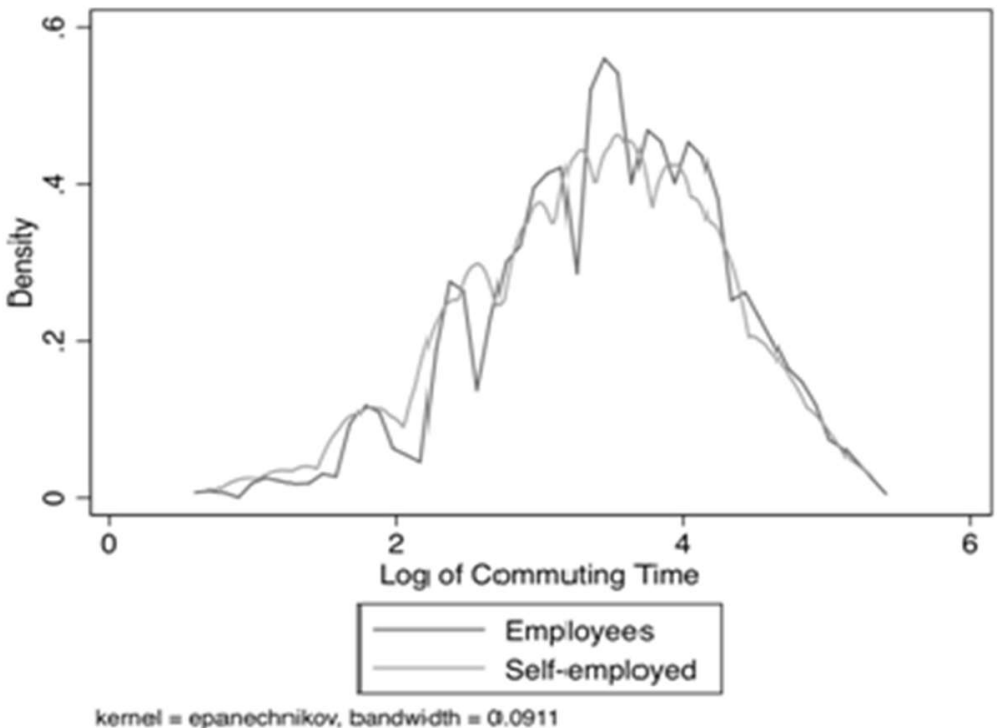

Note: The sample is restricted to individuals between 21 and 65, who are not students and are not retired, working as self-employed or employed, and who work and commute on the diary day, from the ATUS 2003-2014. Commuting time is measured in hours per day. Means are 3.361 in the case of self-employed and 3.464 in the case of employees, and standard deviations are 0.880 and 0.821 , respectively. 
Table 1

Sum Stats of variables, by self-employment status

\begin{tabular}{|c|c|c|c|c|c|c|}
\hline \multirow[t]{2}{*}{ VARIABLES } & \multicolumn{2}{|c|}{ Self-employed } & \multicolumn{2}{|c|}{ Employees } & \multirow[b]{2}{*}{ Diff. } & \multirow[b]{2}{*}{$P$ value } \\
\hline & Mean & S.Dev. & $\underline{\text { Mean }}$ & $\underline{\text { S.Dev }}$ & & \\
\hline Commuting time & 39.702 & $(34.127)$ & 42.273 & $(34.092)$ & -2.570 & $(<0.001)$ \\
\hline \multicolumn{7}{|l|}{ Demographic characteristics } \\
\hline$\overline{\text { Age }}$ & 45.999 & $(10.228)$ & 41.328 & (11.435) & 4.672 & $(<0.001)$ \\
\hline Male & 0.684 & $(0.465)$ & 0.523 & $(0.499)$ & 0.161 & $(<0.001)$ \\
\hline Primary education & 0.057 & $(0.232)$ & 0.086 & $(0.281)$ & -0.029 & $(<0.001)$ \\
\hline Secondary education & 0.253 & $(0.435)$ & 0.297 & $(0.457)$ & -0.044 & $(<0.001)$ \\
\hline University education & 0.690 & $(0.462)$ & 0.617 & $(0.486)$ & 0.073 & $(<0.001)$ \\
\hline White & 0.885 & $(0.319)$ & 0.823 & $(0.382)$ & 0.062 & $(<0.001)$ \\
\hline Citizen & 0.922 & $(0.268)$ & 0.897 & $(0.304)$ & 0.025 & $(<0.001)$ \\
\hline In couple & 0.708 & $(0.455)$ & 0.599 & $(0.490)$ & 0.109 & $(<0.001)$ \\
\hline Partner working & 0.529 & $(0.499)$ & 0.446 & $(0.497)$ & 0.083 & $(<0.001)$ \\
\hline Have children & 0.533 & $(0.499)$ & 0.534 & $(0.499)$ & -0.001 & $(0.870)$ \\
\hline Family size & 2.986 & $(1.517)$ & 2.946 & $(1.491)$ & 0.040 & $(0.122)$ \\
\hline No. weekly working hours & 42.871 & $(20.822)$ & 40.598 & $(14.398)$ & 2.273 & $(<0.001)$ \\
\hline Private vehicle & 0.953 & $(0.212)$ & 0.941 & $(0.237)$ & 0.012 & $(0.003)$ \\
\hline Active commuting & 0.053 & $(0.224)$ & 0.066 & $(0.248)$ & -0.013 & $(0.004)$ \\
\hline Public transport & 0.016 & $(0.127)$ & 0.041 & $(0.198)$ & -0.025 & $(<0.001)$ \\
\hline Other transport & 0.001 & $(0.029)$ & 0.002 & $(0.042)$ & -0.001 & $(0.171)$ \\
\hline \multicolumn{7}{|l|}{ Occupations } \\
\hline$\overline{\text { Management, Business }}$ & 0.270 & $(0.444)$ & 0.169 & $(0.375)$ & 0.101 & $(<0.001)$ \\
\hline Professional & 0.169 & $(0.375)$ & 0.196 & $(0.397)$ & -0.027 & $(<0.001)$ \\
\hline Services & 0.151 & $(0.358)$ & 0.150 & $(0.357)$ & 0.002 & $(0.807)$ \\
\hline Sales & 0.173 & $(0.378)$ & 0.119 & $(0.324)$ & 0.054 & $(<0.001)$ \\
\hline Office and Administration & 0.026 & $(0.158)$ & 0.131 & $(0.337)$ & -0.105 & $(<0.001)$ \\
\hline Farming, fishing & 0.004 & $(0.066)$ & 0.009 & $(0.094)$ & -0.005 & $(0.004)$ \\
\hline Construction & 0.117 & $(0.322)$ & 0.046 & $(0.209)$ & 0.071 & $(<0.001)$ \\
\hline Installation & 0.034 & $(0.182)$ & 0.041 & $(0.199)$ & -0.007 & $(0.045)$ \\
\hline Production & 0.023 & $(0.151)$ & 0.078 & $(0.268)$ & -0.055 & $(<0.001)$ \\
\hline Transportation & 0.032 & $(0.175)$ & 0.061 & $(0.239)$ & -0.029 & $(<0.001)$ \\
\hline \multicolumn{7}{|l|}{ Industries } \\
\hline$\overline{\text { Agriculture, Forestry }}$ & 0.046 & $(0.209)$ & 0.011 & $(0.103)$ & 0.035 & $(<0.001)$ \\
\hline Mining & 0.002 & $(0.049)$ & 0.007 & $(0.082)$ & -0.004 & $(0.002)$ \\
\hline Construction & 0.176 & $(0.381)$ & 0.058 & $(0.235)$ & 0.117 & $(<0.001)$ \\
\hline Manufacturing & 0.038 & $(0.192)$ & 0.152 & $(0.359)$ & -0.114 & $(<0.001)$ \\
\hline Wholesale & 0.136 & $(0.342)$ & 0.167 & $(0.373)$ & -0.032 & $(<0.001)$ \\
\hline Transport & 0.032 & $(0.176)$ & 0.046 & $(0.210)$ & -0.014 & $(<0.001)$ \\
\hline Information & 0.012 & $(0.111)$ & 0.031 & $(0.172)$ & -0.018 & $(<0.001)$ \\
\hline Financial activities & 0.091 & $(0.288)$ & 0.089 & $(0.284)$ & 0.002 & $(0.636)$ \\
\hline Professional and bus. & 0.197 & $(0.398)$ & 0.111 & $(0.314)$ & 0.086 & $(<0.001)$ \\
\hline Education and health & 0.103 & $(0.304)$ & 0.187 & $(0.390)$ & -0.084 & $(<0.001)$ \\
\hline Leisure & 0.069 & $(0.254)$ & 0.087 & $(0.281)$ & -0.018 & $(<0.001)$ \\
\hline \multicolumn{7}{|l|}{ Geographic Characteristics } \\
\hline Metropolitan (center) & 0.200 & $(0.400)$ & 0.234 & $(0.424)$ & -0.035 & $(<0.001)$ \\
\hline Metropolitan (fringe) & 0.625 & $(0.484)$ & 0.616 & $(0.486)$ & 0.009 & $(0.289)$ \\
\hline Non-metropolitan & 0.175 & $(0.380)$ & 0.149 & $(0.356)$ & 0.026 & $(<0.001)$ \\
\hline MSA size: $<1000-000 /$ no $M S A$ & 0.276 & $(0.447)$ & 0.258 & $(0.437)$ & 0.019 & $(0.014)$ \\
\hline MSA size: $100,000-249,999$ & 0.078 & $(0.268)$ & 0.069 & $(0.253)$ & 0.009 & $(0.040)$ \\
\hline MSA size: $250,000-499,999$ & 0.101 & $(0.302)$ & 0.093 & $(0.290)$ & 0.009 & $(0.093)$ \\
\hline MSA size: 500,000-999,999 & 0.097 & $(0.295)$ & 0.099 & $(0.299)$ & -0.003 & $(0.589)$ \\
\hline MSA size: $1,000,000-2,499,999$ & 0.176 & $(0.381)$ & 0.194 & $(0.396)$ & -0.018 & $(0.001)$ \\
\hline MSA size: $2,500,000-4,999,999$ & 0.137 & $(0.344)$ & 0.150 & $(0.357)$ & -0.013 & $(0.041)$ \\
\hline MSA size: $5,000,000+$ & 0.135 & $(0.341)$ & 0.138 & $(0.345)$ & -0.003 & $(0.603)$ \\
\hline
\end{tabular}

Note: Standard deviations in parentheses. The sample is restricted to individuals between 21 and 65 , who are not students and are not retired, working as self-employed or employed, and who work and commute on the diary day, from the ATUS 20032014. Commuting time is measured in minutes per day. P-value of differences are shown in parentheses. 
Table 2. Commuting times, by geographic characteristics

\begin{tabular}{|c|c|c|c|c|}
\hline VARIABLES & Self-employed & Employees & Difference & P value \\
\hline \multicolumn{5}{|l|}{ Metropolitan Status } \\
\hline Metropolitan (center) & $\begin{array}{c}41.425 \\
(34.921)\end{array}$ & $\begin{array}{c}43.009 \\
(34.185)\end{array}$ & -1.584 & $(0.231)$ \\
\hline Metropolitan (fringe) & $\begin{array}{c}41.375 \\
(34.203)\end{array}$ & $\begin{array}{c}43.923 \\
(34.552)\end{array}$ & -2.548 & $(0.008)$ \\
\hline Non metropolitan & $\begin{array}{c}31.752 \\
(31.783)\end{array}$ & $\begin{array}{c}34.301 \\
(30.769)\end{array}$ & -2.549 & $(0.051)$ \\
\hline \multicolumn{5}{|l|}{ MSA size } \\
\hline MSA size: zero/non metrop. & $\begin{array}{c}34.563 \\
(32.442)\end{array}$ & $\begin{array}{c}36.932 \\
(32.123)\end{array}$ & -2.369 & $(0.027)$ \\
\hline MSA size: $100,000-249,999$ & $\begin{array}{c}35.609 \\
(33.272)\end{array}$ & $\begin{array}{c}35.643 \\
(29.566)\end{array}$ & -0.034 & $(0.986)$ \\
\hline MSA size: $250,000-499,999$ & $\begin{array}{c}34.609 \\
(28.709)\end{array}$ & $\begin{array}{c}37.073 \\
(29.370)\end{array}$ & -2.464 & $(0.128)$ \\
\hline MSA size: 500,000-999,999 & $\begin{array}{c}38.098 \\
(29.760)\end{array}$ & $\begin{array}{c}39.959 \\
(31.861)\end{array}$ & -1.861 & $(0.295)$ \\
\hline MSA size: 1,000,000-2,499,999 & $\begin{array}{c}39.458 \\
(31.019)\end{array}$ & $\begin{array}{c}41.870 \\
(31.791)\end{array}$ & -2.412 & $(0.067)$ \\
\hline MSA size: $2,500,000-4,999,999$ & $\begin{array}{c}46.255 \\
(38.272)\end{array}$ & $\begin{array}{c}48.286 \\
(35.722)\end{array}$ & -2.031 & $(0.230)$ \\
\hline MSA size: $5,000,000+$ & $\begin{array}{c}51.233 \\
(39.928)\end{array}$ & $\begin{array}{c}54.740 \\
(40.693)\end{array}$ & -3.507 & $(0.070)$ \\
\hline
\end{tabular}

Note: Standard deviations in parentheses. The sample is restricted to individuals between 21 and 65, who are not students and are not retired, working as self-employed or employed, and who work on the diary day, from the ATUS 2003-2014. Commuting time is measured in minutes per day. Differences are calculated as the overall values of the self-employed minus the overall values of the employed. $P$ value of differences in parentheses. 
Table 3

Regressions of commuting time

\begin{tabular}{|c|c|c|c|c|c|c|c|}
\hline $\log (\operatorname{commuting}$ time) & $\begin{array}{c}\text { (1) } \\
\text { General }\end{array}$ & $\begin{array}{c}\text { (2) } \\
\text { Low income }\end{array}$ & $\begin{array}{c}\text { (3) } \\
\text { Middle } \\
\text { income } \\
\end{array}$ & $\begin{array}{c}\text { (4) } \\
\text { High income }\end{array}$ & $\begin{array}{c}\text { (5) } \\
\text { Short hours }\end{array}$ & $\begin{array}{c}\text { (6) } \\
\text { Mid hours }\end{array}$ & $\begin{array}{c}(7) \\
\text { Long hours }\end{array}$ \\
\hline Employee (ref.: self-employed) & $\begin{array}{c}0.173 * * * \\
(0.019)\end{array}$ & $\begin{array}{c}0.117 * * * \\
(0.041)\end{array}$ & $\begin{array}{c}0.129 * * * \\
(0.030)\end{array}$ & $\begin{array}{c}0.254 * * * \\
(0.031)\end{array}$ & $\begin{array}{c}0.037 \\
(0.052)\end{array}$ & $\begin{array}{c}0.158 * * * \\
(0.032)\end{array}$ & $\begin{array}{c}0.214 * * * \\
(0.028)\end{array}$ \\
\hline Age & $\begin{array}{c}0.0116^{* * * *} \\
(0.004)\end{array}$ & $\begin{array}{l}0.0135 * \\
(0.007)\end{array}$ & $\begin{array}{c}0.008 \\
(0.005)\end{array}$ & $\begin{array}{c}0.012 \\
(0.008)\end{array}$ & $\begin{array}{l}0.0167 * \\
(0.010)\end{array}$ & $\begin{array}{c}0.007 \\
(0.005)\end{array}$ & $\begin{array}{c}0.011 \\
(0.008)\end{array}$ \\
\hline Age squared & $\begin{array}{c}-0.0117 * * * \\
(0.004)\end{array}$ & $\begin{array}{c}-0.0162 * \\
(0.008)\end{array}$ & $\begin{array}{l}-0.008 \\
(0.006)\end{array}$ & $\begin{array}{l}-0.012 \\
(0.009)\end{array}$ & $\begin{array}{l}-0.019 \\
(0.012)\end{array}$ & $\begin{array}{l}-0.006 \\
(0.005)\end{array}$ & $\begin{array}{l}-0.011 \\
(0.009)\end{array}$ \\
\hline Being male & $\begin{array}{c}0.135 * * * \\
(0.013)\end{array}$ & $\begin{array}{c}0.102 * * * \\
(0.027)\end{array}$ & $\begin{array}{c}0.105 * * * \\
(0.019)\end{array}$ & $\begin{array}{c}0.178 * * * \\
(0.022)\end{array}$ & $\begin{array}{c}0.179 * * * \\
(0.047)\end{array}$ & $\begin{array}{c}0.126 * * * \\
(0.017)\end{array}$ & $\begin{array}{c}0.0987 * * * \\
(0.023)\end{array}$ \\
\hline Secondary education & $\begin{array}{c}0.000 \\
(0.023)\end{array}$ & $\begin{array}{c}0.012 \\
(0.036)\end{array}$ & $\begin{array}{l}-0.030 \\
(0.030)\end{array}$ & $\begin{array}{l}0.147^{*} \\
(0.086)\end{array}$ & $\begin{array}{c}0.088 \\
(0.070)\end{array}$ & $\begin{array}{l}-0.025 \\
(0.027)\end{array}$ & $\begin{array}{c}0.019 \\
(0.051)\end{array}$ \\
\hline University education & $\begin{array}{c}0.0486^{* *} \\
(0.023)\end{array}$ & $\begin{array}{c}0.012 \\
(0.039)\end{array}$ & $\begin{array}{c}0.019 \\
(0.031)\end{array}$ & $\begin{array}{c}0.184 * * \\
(0.083)\end{array}$ & $\begin{array}{c}0.056 \\
(0.070)\end{array}$ & $\begin{array}{c}0.012 \\
(0.027)\end{array}$ & $\begin{array}{c}0.103 * * \\
(0.050)\end{array}$ \\
\hline White (ref.: rest of races) & $\begin{array}{c}-0.0289 * \\
(0.015)\end{array}$ & $\begin{array}{l}-0.040 \\
(0.028)\end{array}$ & $\begin{array}{c}-0.0372 * \\
(0.022)\end{array}$ & $\begin{array}{l}-0.030 \\
(0.033)\end{array}$ & $\begin{array}{l}-0.061 \\
(0.052)\end{array}$ & $\begin{array}{l}-0.018 \\
(0.019)\end{array}$ & $\begin{array}{c}-0.0500 * \\
(0.028)\end{array}$ \\
\hline Citizen (ref.: non US-citizen) & $\begin{array}{c}-0.118^{* * *} \\
(0.015)\end{array}$ & $\begin{array}{c}-0.189 * * * \\
(0.029)\end{array}$ & $\begin{array}{c}-0.143 * * * \\
(0.023)\end{array}$ & $\begin{array}{l}-0.037 \\
(0.030)\end{array}$ & $\begin{array}{c}-0.135 * * * \\
(0.049)\end{array}$ & $\begin{array}{c}-0.114 * * * \\
(0.020)\end{array}$ & $\begin{array}{c}-0.112 * * * \\
(0.027)\end{array}$ \\
\hline Living in couple & $\begin{array}{c}0.0998 * * * \\
(0.018)\end{array}$ & $\begin{array}{c}0.115^{* * *} \\
(0.036)\end{array}$ & $\begin{array}{c}0.0878^{* * *} \\
(0.026)\end{array}$ & $\begin{array}{c}0.113 * * * \\
(0.037)\end{array}$ & $\begin{array}{l}0.142 * * \\
(0.058)\end{array}$ & $\begin{array}{c}0.0941 * * * \\
(0.023)\end{array}$ & $\begin{array}{c}0.0923 * * * \\
(0.033)\end{array}$ \\
\hline Labor status of thecouple & $\begin{array}{c}-0.0589 * * * \\
(0.016)\end{array}$ & $\begin{array}{c}-0.0653 * \\
(0.034)\end{array}$ & $\begin{array}{c}-0.0793 * * * \\
(0.023)\end{array}$ & $\begin{array}{c}-0.0704^{* * *} \\
(0.027)\end{array}$ & $\begin{array}{c}-0.123 * * \\
(0.053)\end{array}$ & $\begin{array}{c}-0.0497 * * \\
(0.021)\end{array}$ & $\begin{array}{c}-0.0516^{* *} \\
(0.026)\end{array}$ \\
\hline Have children & $\begin{array}{c}-0.0687 * * * \\
(0.018)\end{array}$ & $\begin{array}{c}-0.0697 * \\
(0.038)\end{array}$ & $\begin{array}{l}-0.040 \\
(0.025)\end{array}$ & $\begin{array}{c}-0.0974 * * * \\
(0.031)\end{array}$ & $\begin{array}{l}-0.113 * \\
(0.060)\end{array}$ & $\begin{array}{c}-0.0925^{* * *} \\
(0.022)\end{array}$ & $\begin{array}{l}-0.009 \\
(0.033)\end{array}$ \\
\hline Family size & $\begin{array}{c}0.0163 * * * \\
(0.006)\end{array}$ & $\begin{array}{c}0.006 \\
(0.014)\end{array}$ & $\begin{array}{c}0.009 \\
(0.008)\end{array}$ & $\begin{array}{c}0.0214^{*} \\
(0.011)\end{array}$ & $\begin{array}{c}0.0359 * \\
(0.019)\end{array}$ & $\begin{array}{c}0.0161 * * \\
(0.008)\end{array}$ & $\begin{array}{c}0.014 \\
(0.012)\end{array}$ \\
\hline No. weekly working hours & $\begin{array}{c}0.00144^{* * *} \\
\quad(0.000)\end{array}$ & $\begin{array}{c}0.00171^{* *} \\
(0.001)\end{array}$ & $\begin{array}{c}0.00196^{* * *} \\
\quad(0.001)\end{array}$ & $\begin{array}{c}0.000 \\
(0.001)\end{array}$ & $\begin{array}{l}-0.002 \\
(0.002)\end{array}$ & $\begin{array}{c}0.00557^{* * *} \\
\quad(0.002)\end{array}$ & $\begin{array}{c}0.001 \\
(0.001)\end{array}$ \\
\hline Private vehicle & $\begin{array}{c}0.613 * * * \\
(0.035)\end{array}$ & $\begin{array}{c}0.651 * * * \\
(0.069)\end{array}$ & $\begin{array}{c}0.618 * * * \\
(0.051)\end{array}$ & $\begin{array}{c}0.601 * * * \\
(0.067)\end{array}$ & $\begin{array}{c}0.495 * * * \\
(0.104)\end{array}$ & $\begin{array}{c}0.555 * * * \\
(0.042)\end{array}$ & $\begin{array}{c}0.760 * * * \\
(0.071)\end{array}$ \\
\hline Public transport & $\begin{array}{c}1.126^{* * *} \\
(0.036)\end{array}$ & $\begin{array}{c}1.306^{* * *} \\
(0.070)\end{array}$ & $\begin{array}{c}1.146^{* * *} \\
(0.053)\end{array}$ & $\begin{array}{c}0.962 * * * \\
(0.061)\end{array}$ & $\begin{array}{c}1.052 * * * \\
(0.108)\end{array}$ & $\begin{array}{c}1.120 * * * \\
(0.046)\end{array}$ & $\begin{array}{c}1.121 * * * \\
(0.066)\end{array}$ \\
\hline Active commuting & $\begin{array}{c}0.0513 * \\
(0.027)\end{array}$ & $\begin{array}{c}0.081 \\
(0.058)\end{array}$ & $\begin{array}{c}0.112 * * * \\
(0.038)\end{array}$ & $\begin{array}{l}-0.009 \\
(0.045)\end{array}$ & $\begin{array}{c}0.035 \\
(0.092)\end{array}$ & $\begin{array}{c}0.0908^{* * *} \\
(0.034)\end{array}$ & $\begin{array}{l}-0.002 \\
(0.046)\end{array}$ \\
\hline Constant & $\begin{array}{c}2.356 * * * \\
(0.109)\end{array}$ & $\begin{array}{c}2.317 * * * \\
(0.208)\end{array}$ & $\begin{array}{c}2.516^{* * *} \\
(0.163)\end{array}$ & $\begin{array}{c}2.183 * * * \\
(0.212)\end{array}$ & $\begin{array}{c}2.727 * * * \\
(0.315)\end{array}$ & $\begin{array}{c}2.398 * * * \\
(0.161)\end{array}$ & $\begin{array}{c}2.213 * * * \\
(0.216)\end{array}$ \\
\hline N. Observations & 32,654 & 7,703 & 14,906 & 10,045 & 2,977 & 18,220 & 11,457 \\
\hline$R$-squared & 0.123 & 0.172 & 0.113 & 0.117 & 0.161 & 0.137 & 0.110 \\
\hline
\end{tabular}

Note: Robust standard errors in parentheses. The sample is restricted to individuals between 21 and 65, who are not students and are not retired, working as self-employed or employed, and with positive time devoted to commuting and paid work, from the ATUS 2003-2014. Column (1) shows the results when all the sample of commuters are considered. Columns (2), (3) and (4) show the results when the sample is restricted to commuters whose yearly family income is lower than $25000 \$$, between $25000 \$$ and $75000 \$$, and higher than $75000 \$$, respectively. Columns (5), (6) and (4) show the results when the sample is restricted to commuters who work less than 20 hours per week, between 20 and 45 hours per week, and more than 45 hours per week. Commuting time is measured in (log) minutes per day. All the Columns include Metropolitan Statistical Area FE (ref.: not identified or non-metropolitan), year FE (ref.: 2003), day-of-the-week FE (ref.: Monday), industry FE (ref.: Agriculture, forestry, fishing, and hunting) and occupation FE (ref.: Management, business, and financial occupations). * Significant at the $90 \%$ level. ** Significant at the $95 \%$ level. *** Significant at the $99 \%$ level. 
Table 4

Regressions on log of commuting time, including geographical information

Variables

\begin{tabular}{cc} 
Geography & Interaction \\
\hline $0.172 * * *$ & -0.036 \\
$(0.020)$ & $(0.076)$ \\
-0.013 & $-0.190 * *$ \\
$(0.040)$ & $(0.091)$ \\
0.043 & -0.086 \\
$(0.038)$ & $(0.085)$ \\
$0.105 * * *$ & -0.048 \\
$(0.038)$ & $(0.085)$ \\
$0.135 * * *$ & 0.030 \\
$(0.036)$ & $(0.077)$ \\
$0.239 * * *$ & 0.069 \\
$(0.040)$ & $(0.081)$ \\
$0.272 * * *$ & $0.162 *$ \\
$(0.042)$ & $(0.083)$ \\
$0.067 * * *$ & -0.018 \\
$(0.014)$ & $(0.045)$ \\
-0.018 & $-0.234 * *$ \\
$(0.038)$ & $(0.090)$
\end{tabular}

Interactions: Employee *
Metropolitan (fringe)

Non metropolitan

MSA size: 100,000-249,999

MSA size: 250,000-499,999

MSA size: 500,000-999,999

MSA size: 1,000,000-2,499,999

MSA size: 2,500,000-4,999,999

MSA size: 5,000,000+

$\begin{array}{cc} & 0.093 * * \\ - & (0.047) \\ - & 0.241 * * \\ - & (0.091) \\ - & 0.199 * * \\ - & (0.091) \\ - & 0.144 * \\ - & (0.085) \\ - & 0.173 * * \\ - & (0.084) \\ - & 0.120 \\ - & (0.075) \\ - & 0.190 * * \\ - & (0.078) \\ - & 0.124 \\ - & (0.079) \\ & 2.229 * * * \\ (0.119) & (0.135) \\ 31,178 & 31,178 \\ 0.134 & 0.135\end{array}$

N. Observations

0.134

0.135

Note: Robust standard errors in parentheses. The sample is restricted to individuals between 21 and 65 , who are not students and are not retired, working as self-employed or employed, and who work and commute on the diary day, from the ATUS 2003-2014. Commuting time is measured in log of minutes per day. All the Columns include Metropolitan Statistical Area FE (ref.: not identified or non-metropolitan), year FE (ref.: 2003), day-of-the-week FE (ref.: Monday), industry FE (ref.: Agriculture, forestry, fishing, and hunting) and occupation FE (ref:: Management, business, and financial occupations). Additional results for age, gender, education, race, citizenship status, marital status, labor force status of the partner, the presence of children, family size, the number of working hours, and the type of commuting, are shown in Table A2 of the Appendix. * Significant at the 90\% level. ** Significant at the $95 \%$ level. $* * *$ Significant at the $99 \%$ level. 


\section{Appendix A}

\section{Table A1}

Alternative results including non-commuters in the sample

\begin{tabular}{|c|c|c|c|c|}
\hline & (1) & (2) & (3) & (4) \\
\hline \multicolumn{5}{|c|}{ Heckman model } \\
\hline & $\begin{array}{c}\text { Commuting } \\
\text { time }\end{array}$ & $\begin{array}{c}\text { Selection } \\
\text { model }\end{array}$ & Tobit & $\begin{array}{l}\text { Probit (zero } \\
\text { commuting) }\end{array}$ \\
\hline Employee (ref.: self-employed) & $\begin{array}{c}0.179 * * * \\
(0.0130)\end{array}$ & - & $\begin{array}{c}0.255 * * * \\
(0.0202)\end{array}$ & $\begin{array}{c}-0.654 * * * \\
(0.029)\end{array}$ \\
\hline Age & $\begin{array}{c}0.00670 * * \\
(0.00265)\end{array}$ & - & $\begin{array}{c}0.00991 * * \\
(0.00419)\end{array}$ & $\begin{array}{l}0.014 * \\
(0.007)\end{array}$ \\
\hline Age squared & $\begin{array}{c}-0.00713^{* *} \\
(0.00310)\end{array}$ & - & $\begin{array}{l}-0.0125 * * \\
(0.00492)\end{array}$ & $\begin{array}{l}-0.006 \\
(0.008)\end{array}$ \\
\hline Secondary education & $\begin{array}{c}-0.0514 * * * \\
(0.0180)\end{array}$ & - & $\begin{array}{l}-0.0330 \\
(0.0265)\end{array}$ & $\begin{array}{l}0.086^{*} \\
(0.052)\end{array}$ \\
\hline University education & $\begin{array}{c}-0.0490^{* * *} \\
(0.0180)\end{array}$ & - & $\begin{array}{l}-0.0233 \\
(0.0269)\end{array}$ & $\begin{array}{c}0.180 * * * \\
(0.050)\end{array}$ \\
\hline White (ref.: rest of races) & $\begin{array}{c}-0.0382 * * * \\
(0.0117)\end{array}$ & - & $\begin{array}{c}-0.0338 * \\
(0.0181)\end{array}$ & $\begin{array}{l}-0.013 \\
(0.032)\end{array}$ \\
\hline Citizen (ref.: non US-citizen) & $\begin{array}{c}-0.139 * * * \\
(0.0122)\end{array}$ & - & $\begin{array}{c}-0.148^{* * *} \\
(0.0183)\end{array}$ & $\begin{array}{c}0.209 * * * \\
(0.032)\end{array}$ \\
\hline No. weekly working hours & $\begin{array}{c}0.00186^{* * *} \\
(0.000281)\end{array}$ & - & $\begin{array}{c}0.00149^{* * *} \\
(0.000451)\end{array}$ & $\begin{array}{c}-0.003 * * * \\
(0.001)\end{array}$ \\
\hline Private vehicle & $\begin{array}{c}2.989 * * * \\
(0.0111)\end{array}$ & - & $\begin{array}{l}3.594 * * * \\
(0.0284)\end{array}$ & - \\
\hline Public transport & $\begin{array}{c}2.332 * * * \\
(0.0266)\end{array}$ & - & $\begin{array}{c}2.645 * * * \\
(0.0736)\end{array}$ & - \\
\hline Active commuting & $\begin{array}{c}1.129 * * * \\
(0.0204)\end{array}$ & - & $\begin{array}{c}1.339 * * * \\
(0.0529)\end{array}$ & - \\
\hline Being male & - & $\begin{array}{c}0.167 * * * \\
(0.0155)\end{array}$ & $\begin{array}{c}0.153 * * * \\
(0.0150)\end{array}$ & $\begin{array}{c}-0.077 * * * \\
(0.025)\end{array}$ \\
\hline Living in couple & - & $\begin{array}{l}0.389 * * * \\
(0.0247)\end{array}$ & $\begin{array}{l}0.0528^{* *} \\
(0.0208)\end{array}$ & $\begin{array}{l}-0.018 \\
(0.037)\end{array}$ \\
\hline Labor status of the couple & - & $\begin{array}{c}0.0932 * * * \\
(0.0239)\end{array}$ & $\begin{array}{c}-0.0534 * * * \\
(0.0173)\end{array}$ & $\begin{array}{c}0.019 \\
(0.031)\end{array}$ \\
\hline Have children & - & $\begin{array}{c}0.0128 \\
(0.0215)\end{array}$ & $\begin{array}{c}-0.111^{* * *} \\
(0.0206)\end{array}$ & $\begin{array}{c}0.095 * * * \\
(0.035)\end{array}$ \\
\hline Family size & - & $\begin{array}{c}-0.0995 * * * \\
(0.00707)\end{array}$ & $\begin{array}{l}0.0171 * * \\
(0.00785)\end{array}$ & $\begin{array}{l}-0.008 \\
(0.014)\end{array}$ \\
\hline Lambda & $\begin{array}{c}-0.471 * * * \\
(0.0609)\end{array}$ & - & - & - \\
\hline Constant & $\begin{array}{c}0.414 * * * \\
(0.0740)\end{array}$ & $\begin{array}{c}1.067 * * * \\
(0.0181)\end{array}$ & $\begin{array}{c}-0.703^{* * *} \\
(0.120)\end{array}$ & $\begin{array}{l}-0.042 \\
(0.180)\end{array}$ \\
\hline N. Observations & 44,623 & 44,623 & 38,687 & 38,687 \\
\hline
\end{tabular}

Note: Robust standard errors in parentheses. The sample is restricted to individuals between 21 and 65 , who are not students and are not retired, working as self-employed or employed, from the ATUS 2003-2014. Column (2) also includes those who report themselves as not-working, and the selection equation analyzes "being working as employee or self-employed" as selection category. Commuting time is measured in (log) minutes per day. Columns (3) and (4) include employed and self-employed non-commuters on the day of the survey. Columns (1), (3) and (4) include Metropolitan Statistical Area FE (ref.: not identified or nonmetropolitan), year FE (ref.: 2003), day-of-the-week FE (ref.: Monday), industry FE (ref.: Agriculture, forestry, fishing, and hunting) and occupation FE (ref.: Management, business, and financial occupations). * Significant at the $90 \%$ level. ** Significant at the $95 \%$ level. *** Significant at the $99 \%$ level. 
Table A2

Additional results for socio-demographic variables

\begin{tabular}{|c|c|c|}
\hline Variables & Geography & Interaction \\
\hline$\overline{\text { Age }}$ & $\begin{array}{c}0.012 * * * \\
(0.004)\end{array}$ & $\begin{array}{c}0.012 * * * \\
(0.004)\end{array}$ \\
\hline Age squared & $\begin{array}{c}-0.013 * * * \\
(0.004)\end{array}$ & $\begin{array}{c}-0.013 * * * \\
(0.004)\end{array}$ \\
\hline Being male & $\begin{array}{c}0.127 * * * \\
(0.013)\end{array}$ & $\begin{array}{c}0.127 * * * \\
(0.013)\end{array}$ \\
\hline Secondary education & $\begin{array}{c}-0.019 \\
(0.023)\end{array}$ & $\begin{array}{l}-0.018 \\
(0.023)\end{array}$ \\
\hline University education & $\begin{array}{c}0.030 \\
(0.023)\end{array}$ & $\begin{array}{c}0.031 \\
(0.023)\end{array}$ \\
\hline White (ref:: rest of races) & $\begin{array}{c}-0.037^{* * *} \\
(0.015)\end{array}$ & $\begin{array}{c}-0.037^{* * *} \\
(0.015)\end{array}$ \\
\hline Citizen (ref.: non US-citizen) & $\begin{array}{c}-0.057 * * * \\
(0.019)\end{array}$ & $\begin{array}{c}-0.057^{* * *} \\
(0.019)\end{array}$ \\
\hline Living in couple & $\begin{array}{c}0.109 * * * \\
(0.019)\end{array}$ & $\begin{array}{c}0.109 * * * \\
(0.019)\end{array}$ \\
\hline Labor status of the couple & $\begin{array}{c}-0.060 * * * \\
(0.016)\end{array}$ & $\begin{array}{c}-0.059 * * * \\
(0.016)\end{array}$ \\
\hline Have children & $\begin{array}{c}-0.069 * * * \\
(0.018)\end{array}$ & $\begin{array}{c}-0.068^{* * *} \\
(0.018)\end{array}$ \\
\hline Family size & $\begin{array}{c}0.017 * * \\
(0.007)\end{array}$ & $\begin{array}{c}0.017 * * \\
(0.007)\end{array}$ \\
\hline No. weekly working hours & $\begin{array}{c}0.002^{* * * *} \\
(0.001)\end{array}$ & $\begin{array}{c}0.002 * * * \\
(0.001)\end{array}$ \\
\hline Private vehicle & $\begin{array}{c}0.611^{* * * *} \\
(0.036)\end{array}$ & $\begin{array}{c}0.611 * * * \\
(0.036)\end{array}$ \\
\hline Public transport & $\begin{array}{c}1.106 * * * \\
(0.037)\end{array}$ & $\begin{array}{c}1.106 * * * \\
(0.037)\end{array}$ \\
\hline Active commuting & $\begin{array}{l}0.045^{*} \\
(0.027)\end{array}$ & $\begin{array}{l}0.047^{*} \\
(0.027)\end{array}$ \\
\hline Constant & $\begin{array}{c}2.032 * * * \\
(0.119)\end{array}$ & $\begin{array}{c}2.229 * * * \\
(0.135)\end{array}$ \\
\hline Industry FE & Yes & Yes \\
\hline $\begin{array}{l}\text { Occupation FE } \\
\text { Day FE }\end{array}$ & $\begin{array}{l}\text { Yes } \\
\text { Yes }\end{array}$ & $\begin{array}{l}\text { Yes } \\
\text { Yes }\end{array}$ \\
\hline Year FE & Yes & Yes \\
\hline$M S A F E$ & Yes & Yes \\
\hline $\begin{array}{l}\text { N. Observations } \\
R \text {-squared }\end{array}$ & $\begin{array}{c}31,178 \\
0.134\end{array}$ & $\begin{array}{c}31,178 \\
0.135\end{array}$ \\
\hline
\end{tabular}

Note: Robust standard errors in parentheses. The sample is restricted to individuals between 21 and 65, who are not students and are not retired, working as self-employed or employed, and who work and commute on the diary day, from the ATUS 2003-2014. Commuting time is measured in $\log$ of minutes per day. Main results are shown in Table 4. All the Columns include Metropolitan Statistical Area FE (ref.: not identified or non-metropolitan), year FE (ref.: 2003), day-of-the-week FE (ref.: Monday), industry FE (ref.: Agriculture, forestry, fishing, and hunting) and occupation FE (ref:: Management, business, and financial occupations). * Significant at the $90 \%$ level. ** Significant at the $95 \%$ level. $* * *$ Significant at the $99 \%$ level. 